0

doi: $10.5004 /$ dwt.2021.27613

\title{
Water quality determination by using phytoplankton composition in sea bass (Dicentrarchus labrax, L., 1758) aquaculture ponds in Turkey
}

\author{
Nese Yilmaz ${ }^{\mathrm{a}, *}$, Remziye Eda Yardimci ${ }^{\mathrm{b}}$, Ali Torabi Haghighi ${ }^{\mathrm{c}}$, Mohamed Elhag ${ }^{\mathrm{d}, \mathrm{e}, \mathrm{f}}$, \\ Ahmet Celebis \\ 'Department of Freshwater Resources and Management, Faculty of Aquatic Sciences, Istanbul University, 34134 Laleli, Istanbul, \\ Turkey, Tel.+902124555700; email: nyilmaz@istanbul.edu.tr \\ ${ }^{b}$ Department of Aquaculture and Fish Diseases, Faculty of Aquatic Sciences, Istanbul University, 34134 Laleli, Istanbul, Turkey, \\ Tel. +90 21245557 00; email: etepecik@istanbul.edu.tr \\ 'Water, Energy and Environmental Engineering Research Unit, Faculty of Technology, University of Oulu, 90014 Oulu, Finland, \\ Tel.+358 404492894; email: ali.torabihaghighi@oulu.fi \\ 'Department of Hydrology and Water Resources Management, Faculty of Meteorology, Environment and Arid Land Agriculture, \\ King Abdulaziz University, Jeddah 21589, Saudi Arabia, Tel. +966 557653684; email: melhag@kau.edu.sa \\ 'Institute of Remote Sensing and Digital Earth (RADI), Chinese Academy of Science (CAS), Beijing 100094, China \\ ${ }^{f}$ Department of Applied Geosciences, Faculty of Science, German University of Technology in Oman, Muscat 1816, Oman \\ 8 Department of Environmental Engineering, Sakarya University, Faculty of Engineering, 54050 Esentepe, Sakarya, Turkey, \\ Tel.+90264 29559 47; email: ahmetc@sakarya.edu.tr
}

Received 1 April 2021; Accepted 16 July 2021

\section{A B S T R A C T}

In this study, the phytoplankton composition and some water quality parameters of cultured sea bass (Dicentrarchus labrax, L., 1758) earthen ponds were investigated in Muğla Province, Turkey. Sea bass which production significantly increased since the 1980s, is accepted as one of the popular species in the Mediterranean region. Samples were collected from the fish farm when algal blooms are observed in May 2017, from 6 sampling points, including the main drainage, clean water, and 4 earthen ponds. In total 31 taxa belonging to 7 divisions as Bacillariophyta (13), Charophyta (1), Chlorophyta (7), Cryptophyta (2), Cyanobacteria (3), Euglenozoa (4), and Ochrophyta (1) of phytoplankton were determined. Recorded species of the phytoplankton indicated organic pollution at the studied earthen ponds. Excessive algal blooms, particularly caused by blue-green algae, pose a great threat to all fish farm organisms by causing massive fish deaths in aquaculture ponds. The toxin-producing Cyanobacteria Microcystis aeruginosa (Kütz.) Kützing and Merismopedia glauca (Ehr.) Kützing were found often in water samples. Since pond management is essential for a productive fish farm obtained results indicated that the first step to enhancing good quality products in the aquaculture sector should have the sustainable monitoring of phytoplankton by farmers and adequate supplying water.

Keywords: Aquaculture; Phytoplankton; Water quality; Earthen ponds; Turkey

\footnotetext{
${ }^{*}$ Corresponding author.
} 


\section{Introduction}

Fish is an inexpensive source of high protein and also, the fishery has become a significant income in many countries. Water is essential for fish to sustain their life functions like other living beings [1]. In recent years the natural seafood has been decreasing day by day, owing to various reasons and aquaculture shows a rapid increase in Turkey as well as all over the world [2]. It is expected that the production amounts by aquaculture would pass the production amounts by hunting shortly soon. There should be carried out detailed studies on this subject to obtain higher quality and more economical aquaculture products. Especially in the Aegean and Mediterranean regions in Turkey, aquaculture conducted at land ponds has become a significant sector. Offering fish grown at land ponds to buyers at lower prices, ease of maintenance, and feeding make the production at earthen ponds more preferable and attractive [3].

Fish farming is accepted as the main healthy source of animal food scarcity caused by the world's overpopulation and climate change. Nowadays, gilt-head sea bream (Sparus aurata), and sea bass are the most intensively cultivated marine fish species. Besides, alternative fish species for aquaculture are turbot (Psetta maxima), meagre (Argyrosomus regius), red sea bream (Pagrus major), sharpsnout sea bream (Diplodus puntazzo), and common dentex (Dentex dentex). Dicentrarchus labrax, Linnaeus (1758), the sea bass is the most popular species in Mediterranean aquaculture. Its production started in the 1980s and has come up by multiplying day after day. The first sea bass hatchery in Turkey was established in 1990 with the agreement signed by FAO (Food and Agricultural Organization of the United Nations), Italy, and Turkey. The facility of the hatchery started to operate in 1993. The sea bass production constitutes approximately $70 \%$ of the total fish breeding production of Turkey. Muğla is located in the south-western part of Turkey, has a long sea coast, and is the first city in Turkey in terms of fish farms and production amount [3]. It is clear that overpopulation caused high pressure on the protein-rich food source fish, and the fish product demand has increased in recent years.

Water quality management to meet current food demand is one of the main issues that need to be taken into consideration in fish farms ponds. Optimum fish production in aquaculture largely depends on the physicochemical and biological properties of the used water. For this reason, successful pond management needs a good understanding of the water quality. Water temperature, dissolved oxygen, $\mathrm{pH}$, and phytoplankton composition are the main variables to determine the water quality in ponds [4]. Phytoplankters, the primary producers in the food chain, have a vital role in fish production in aquatic environments [5]. Many benefits of microalgae are known, such as supplying oxygen in fish farms, utilization of harmful ammonia and nitrites, improving discharge wastewater by removing nitrogen and phosphorus, and providing supplementary food for fish. Phytoplankton, which is used as a live feed source in fish farming due to its rich source of proteins, lipids and carbohydrates, can also be poisonous for many living organisms, including humans by producing toxins [6]. They are one of the bioindicators of water quality because they react very fast when changes occur in aquatic systems $[4,7,8$,$] .$ Since aquaculture is affected highly by the density and diversity of phytoplankton in waters, phytoplankton species can be used as biomarkers for water pollution assessment in fish production $[9,10]$. Artificial feeds and fertilizers used in fish farms ensure the enrichment of the fish pond water regarding nutrient salt concentrations. Therefore, nutrient increases in the ponds support the increase in the phytoplankton density. Also, undesirable algal blooms lead to deterioration in the quality of water in fish breeding ponds [7]. For this reason, phytoplankton composition was determined in the water of the ponds at the fish farm.

Many limnological studies have been carried out on phytoplankton communities and related water quality parameters in Turkey's inland waters [11-13]. Studies on phytoplankton in aquaculture fish ponds, contrary to other countries, have a shortcoming in Turkey. This study aims to designate the phytoplankton species causing problems in aquaculture fish ponds, to resolve the lack of research, and take attention to this subject.

\section{Material and methods}

Water samples were collected from the surface water by Nansen bottles from 6 different points, including the main drainage, the clean water, and 4 earthen ponds from the fish farm (Muğla, Turkey) when the algal blooms occurred in May 2017. The location of the fish farm is shown in Fig. 1 and the views of land ponds are given in Fig. 2. Collected samples are fixed with Lugol's iodine solution in the study area for phytoplankton identification. All recorded species were checked in algabase cite according to Guiry and Guiry [14]. Phytoplankton identification has been made with a Nikon-made microscope, using the literature of several comprehensive reviews on the subject in the laboratory [15-24]. Phytoplankton counting was not possible due to the intense particulate matter in the water samples. Water temperature, dissolved oxygen, $\mathrm{pH}$, and salinity of each sampling point were measured using the WTW Multi 340i/set multiparameter in the field.

Palmer [25] developed an index to determine the trophic stage of freshwaters by using phytoplankton species. Palmer index is based on a total of 20 phytoplankton genera that have organic pollution tolerance in waters. It was given scores according to tolerances to organic contamination for each specified species in a range from 1 to 5 . If the total calculation values are equal to 20 and above indicate high organic pollution, values between 15 to 19 moderate pollution and values below 15 indicate no organic pollution [13].

\section{Results and discussion}

The water temperature varied from $7^{\circ} \mathrm{C}$ to $8^{\circ} \mathrm{C}$ in winter, depending on the weather temperature. The $\mathrm{pH}$ changed from 7.0 to 7.5 and salinity varied between $8 \%$ ond $11 \%$ of artesian well water. The salinity concentration is an affecting factor for fish species development where aquaculture activities occur [26]. The measured dissolved oxygen concentration at the ponds was very low $(5 \mathrm{mg} / \mathrm{L})$. Oxygen level has been kept around $8 \mathrm{mg} / \mathrm{L}$ by using mechanical 




Fig. 1. Map of the location of the fish farm.
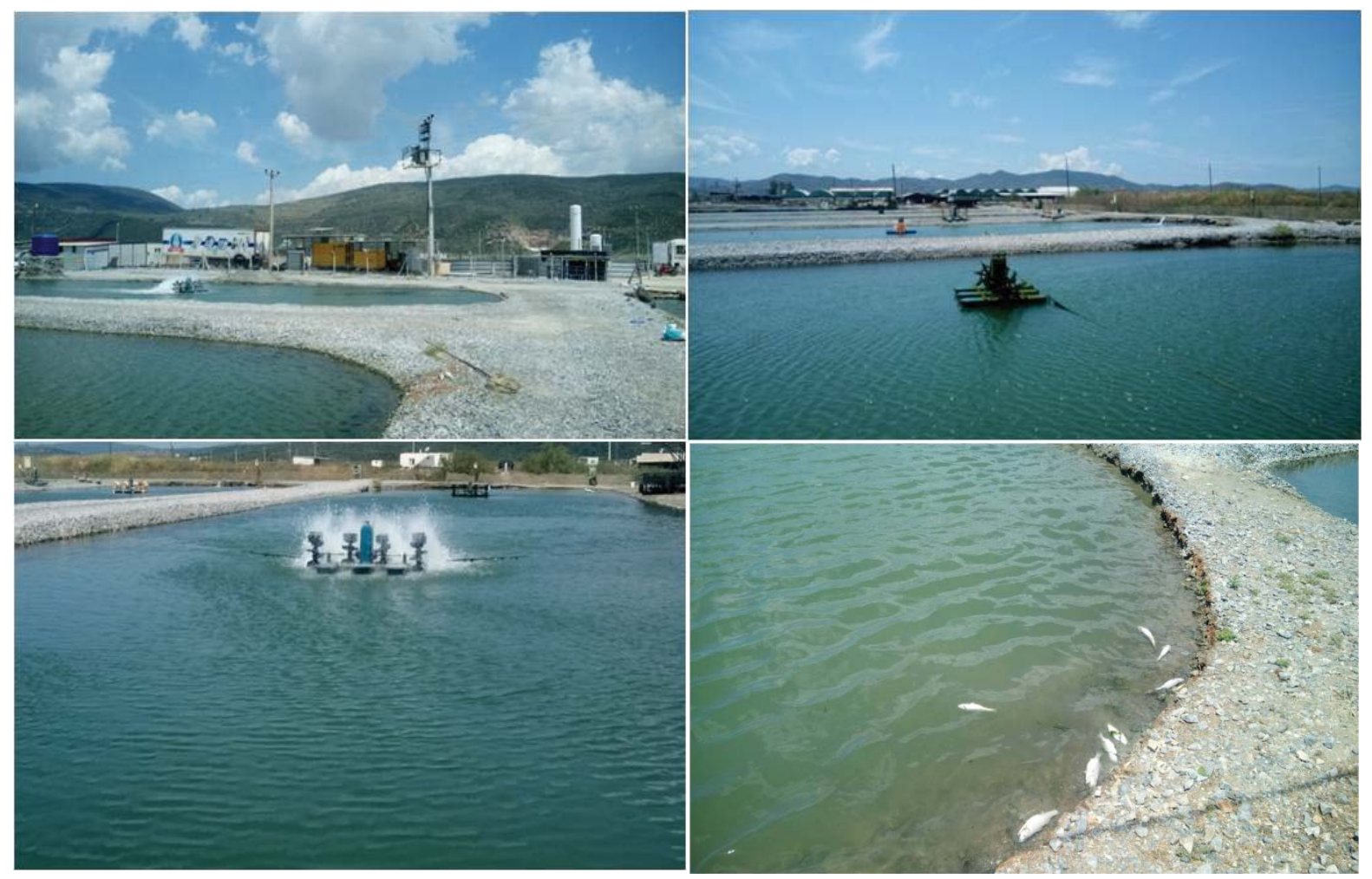

Fig. 2. Views of sampled fish farm ponds.

methods at night especially. Dissolved oxygen concentrations indicate the pollution status of water [5].

In all 31 species belonging to Bacillariophyta (13), Charophyta (1), Chlorophyta (7), Cryptophyta (2), Cyanobacteria (3), Euglenozoa (4), and Ochrophyta (1) divisions were recorded. The list of identified phytoplankton species is given in Table 1 . The water samples except the shallow ponds had high turbidity and contained a high amount of particulate matter in general. Under unsuitable environmental conditions and stress, fish secrete excessive mucus in ponds. In addition, unused feeds, feed residues, and fish feces, except for the secreted mucus, also contributed to the enrichment of the pond water with particulate matter and increased turbidity [27]. This situation prevented the counting and density calculation of phytoplanktonic organisms.

Phytoplankton composition at sampling ponds was composed mainly of Bacillariophyta, Chlorophyta, and Euglenozoa members. Cyclotella meneghiniana of diatoms, Scenedesmus spp. of green algae, Cryptomonas ovata of cryptomonads, Euglena gracilis, and E. viridis of euglenoids were detected almost in all sampling pools. Euglenozoa members were not found in shallow ponds while Chroococcus limneticus and Merismopedia glauca of Cyanobacteria were recorded. Also, Plagioselmis nannoplanctonica of Cryptophyta was present only in shallow 
Table 1

List of identified taxa of phytoplankton in fish ponds

\begin{tabular}{ll}
\hline DIVISIO: BACILLARIOPHYTA & DIVISIO: CHAROPHYTA \\
\hline Achnanthes lanceolata (Bréb. ex Kütz.) Grunow & Cosmarium formosulum Hoff. \\
Amphora ovalis (Kützing) Kützing & \\
Cocconeis placentula Ehrenberg & \\
Cyclotella meneghiniana Kützing & DIVISIO: CRYPTOPHYTA \\
Cymbella affinis Kützing & Cryptomonas ovata Ehrenberg \\
Diatoma vulgaris Bory & Plagioselmis nannoplanctonica (Skuja) G. Novarino, I.A.N. Lucas and Morrall \\
Meridion circulare (Greville) C. Agardh & \\
Navicula cryptocephala Kützing & \\
Nitzschia acicularis (Kützing) W. Smith & DIVISIO: CYANOBACTERIA \\
Pleurosigma sp. & Chroococcus limneticus Lemmermann \\
Stephanodiscus astrea (Kützing) Grunow & Microcystis aeruginosa (Kützing) Kützing \\
Ulnaria acus (Kützing) Aboal & Merismopedia glauca (Ehrenberg) Kützing \\
Ulnaria ulna (Nitzsch) Compère & \\
DIVISIO: CHLOROPHYTA & DIVISIO: EUGLENOZOA \\
Coelastrum microporum Nägeli & Euglena acus (O.F. Müller) Ehrenberg \\
Kirchneriella sp. & Euglena gracilis G.A. Klebs \\
Pandorina morum (O.F. Müller) Bory & Euglena viridis (O.F. Müller) Ehrenberg \\
Scenedesmus ecornis (Ehrenberg) Chodat & Trachelomonas hispida (Perty) F. Stein \\
Scenedesmus quadricauda (Turpin) Brébisson & \\
Scenedesmus sp. & DIVISIO: OCHROPHYTA \\
Sphaerocystis sp. & Dinobryon sertularia Ehrenberg \\
\hline
\end{tabular}

ponds. Particularly, Microcystis aeruginosa and Merismopedia glauca of toxin-producing blue-green algae, and species of Euglena genus are accepted indicators of organic pollution, and they were found quite often in water samples at ponds [12]. Photosynthesis increased by the influence of sunlight promotes free $\mathrm{CO}_{2}$ organic production and consequently the growth of the genus Euglena. Extravagant Cyanobacteria blooms may cause a warning to the fish farm living beings. In this study, blue-green algae were found often but not heavily. According to the recorded species of phytoplankton, ponds were determined as organically polluted. Species mainly belonging to Cyanobacteria, Chlorophyta, Bacillariophyta, and Euglenozoa groups were identified in studies conducted in fish ponds in many countries [4,7,28,]. Microcystis sp. and Anabaena sp. were recorded as the dominant genera in aquaculture ponds in Bangladesh when Cyanobacteria were recorded in high abundance in spring and early autumn [7]. In a study conducted in urban wastewater-fed fish ponds in India by Das et al. [4], the percentage contribution of Chlorophyceae was the highest followed by Cyanophyceae and Bacillariophyceae, respectively. Euglena acus and Phacus of Euglenozoa division were determined only in the high organically polluted pond. In another study carried out on phytoplankton in cultured ponds of two fish farms in Bangladesh, the species Euglena, Microcystis and Eurolena were identified as dominant [27]. In shrimp ponds, it is reported that Euglenophyta like Euglena may become a threat when ammonia and mucus are expelled to water [6].

Phytoplankton functional groups have been employed to indicate environmental conditions and have proved to be more precise than phylogenetic grouping [29]. The phytoplankton functional groups comprised more than 45 assemblages nominated by alphanumerical codes concerning their survival strategies, tolerance, and sensitivities. In terms of the functional groups, phytoplankton formed 15 groups: C, D, E, G, N, X2, Y, F, J, $\mathrm{L}_{0}, \mathrm{M}, \mathrm{M}_{\mathrm{P}}, \mathrm{T}_{\mathrm{B}^{\prime}} \mathrm{W} 1$, and W2. The phytoplankton composition of land ponds was mainly represented by C, J, Y, and W1 assembladges, which included the characteristic species of mesotrophic and eutrophic waters at the ponds (Table 2). Cyclotella meneghiniana of Bacillariophyta placed in Codon C, occupies a habitat described as eutrophic small and medium-sized lakes with tolerances to light and $\mathrm{C}$ deficiency; sensitivities of $\mathrm{pH}$ rise, Si depletion stratification. The J assemblage consisted of Coelastrum microporum, Scenedsmus ecornis, Scenedesmus quadricauda, and Scenedesmus sp., which are characteristic of shallow, enriched lakes, ponds and rivers. Scenedesmus genera members are prominent in shallow, highly enriched systems and they are found frequently dominant in freshwater lakes and rivers [30,31]. The habitat of Codon $\mathrm{Y}$ is usually small, enriched lakes and is represented by Cryptomonas ovata at the land ponds. W1 assemblage consisted of the euglenoids Euglena acus, Euglena gracilis, and Euglena viridis which were recorded in all sampling points. Euglenozoa (Euglenophyta) division members are reported more abundant in organically polluted waters [32]. According to Palmer's index [25], the recorded genera at the ponds in the fish farm were calculated as a score of 19 (Table 3), and the water of the ponds was found as in the high organic pollution level.

Rapid algal development may block the air connection from the atmosphere by covering the surface of the water. 
Table 2

Functional groups of recorded phytoplankton species [30,31]

\begin{tabular}{lll}
\hline Codon & Typical represantatives & Habitat \\
\hline $\mathrm{C}$ & Cyclotella meneghiniana, Stephanodiscus astrea & Eutrophic small and medium sized lakes \\
$\mathrm{D}$ & Nitzschia acicularis, Ulnaria acus, Ulnaria ulna & Shallow, enriched turbid waters including rivers \\
$\mathrm{N}$ & Cosmarium formosulum & Mesotrophic epilimnia \\
$\mathrm{T}_{\mathrm{B}}$ & Achnanthes lanceolata & Highly lotic environments \\
$\mathrm{X} 2$ & Plagioselmis nannoplanctonica & Shallow, meso-eutrophic environments \\
$\mathrm{Y}$ & Cryptomonas ovata & Usually small, enriched lakes \\
$\mathrm{E}$ & Dinobryon sertularia & Usually small, oligotrophic, base poor lakes or heterotrophic ponds \\
$\mathrm{F}$ & Kirchneriella sp., Sphaerocystis sp. & Clear epilimnia, clear deeply mixed mesoeutrophic lakes \\
$\mathrm{G}$ & Pandorina morum & Small eutrophic lakes and very stable phases in larger river-fed \\
& & basins and storage reservoirs. Short, nutrient-rich water columns \\
$\mathrm{J}$ & Coelastrum microporum, Scenedesmus ecornis, & Shallow, highly enriched lakes, ponds and rivers \\
& Scenedesmus quadricauda, Scenedesmus sp. & \\
$\mathrm{L}_{\mathrm{O}}$ & Chroococcus limneticus, Merismopedia glauca & Summer epilimnia in mesotrophic lakes \\
$\mathrm{M}$ & Microcystis aeruginosa & Dielly mixed layers of small, eutrophic, low latitude lakes \\
$\mathrm{M}_{\mathrm{P}}$ & Cocconeis placentula, Cymbella affinis, Navicula & Frequently-stirred-up, inorganically turbid shallow lakes \\
& cryptocephala & \\
$\mathrm{W} 1$ & Euglena acus, Euglena gracilis, Euglena viridis & Ponds, even temporary, rich in organic matter from husbandary or \\
& & sewages \\
W2 & Trachelomonas hispida & Shallow mesotrophic lakes \\
\hline
\end{tabular}

Table 3

Pollution index of algal genera according to Palmer [25] at fish ponds

\begin{tabular}{lll}
\hline Diviso & Genus & Pollution index score \\
\hline Bacillariophyta & Cyclotella & 1 \\
& Navicula & 3 \\
& Nitzschia & 3 \\
& Ulnaria & 2 \\
& (Syn. Synedra) & \\
Chlorophyta & Pandorina & 1 \\
& Scenedesmus & 4 \\
Cyanobacteria & Microcystis & 1 \\
& (Syn. Anacytis) & \\
Euglenozoa & Euglena & 5 \\
Calculated Palmer index & 20 (high organic pollution) \\
\hline
\end{tabular}

This situation causes a fast decrease in the oxygen concentration of the water. One of the significant damage-giving reasons for aquaculture is the sudden drop in oxygen concentration at the ponds. The relationship between dissolved oxygen and phytoplankton density was studied in many investigations [33-35]. Nutrient-rich waters support a high photosynthesis rate causing increases in phytoplankton biomass in ponds [36-38]. Appropriate nutrient salt concentrations would allow the right biomass and composition of phytoplankton assemblages. Excessive supplies of nutrients may cause enrichments in water which promote algal blooms, growth of macrophytes and also primary production. Fish mortality may occur at aquaculture ponds as a result of hypoxia and anoxia which produced by excessive algal blooms [6]. Especially Cyanobacteria can lead to surface scums in waters. Scum formation is an indication of eutrophication and usually results in increased $\mathrm{pH}$ in aquatic systems. Mainly Anabaena and Anacystis (Microcystis) of Cyanobacteria are known scum-producing toxic species [39]. On the other hand, Smith and Piedrahita [33], suggested increasing the algal growth instead of reducing the algae biomass in order to increase the dissolved oxygen level in aquaculture with their mathematical modeling developed in a catfish pool where the relationship between phytoplankton density and dissolved oxygen was examined.

\section{Conclusion}

Establishment costs of earthen pool facilities are very low compared to other production facilities, but the fact that they are not designed in accordance with the capacity and that the business is not managed well causes great problems. Principles of water management in aquaculture are a daily topic because water quality parameters affect fish production at the ponds. Nowadays, growing demands in the world because of food sources exhausted, and population pressure on these sources are increasingly required, getting optimum conditions for increasing the fish yields. Water quality is the major factor in producing healthy fish for efficient fish farming. If the water has not have optimum conditions for aquaculture, the fish could not feed or grow well. It is not enough to have information on physical and chemical variables of the used water in fisheries for the selected cultured fish species' optimal growth. Also, the environmental conditions of produced or planned fish farms should be well known.

A total of 31 taxa belong to 7 divisions of phytoplankton were identified in the sea bass fish farm ponds. Microcystis 
aeruginosa and Merismopedia glauca of toxin-producing blue-green algae, organic pollution indicators Euglena acus, Euglena gracilis and Euglena viridis of Euglenophyta were found often in water samples at the studied earthen ponds. Also, the dissolved oxygen concentration at the ponds was very low. Since aquaculture has high-risk efforts, the dynamics related to environmental changes such as temperature, water movement, light, soil, and other biological factors lead to changes in phytoplankton species and the food chain. For this purpose, physicochemical and biological water quality parameters of water should be monitor together in daily periods in fish farms. Periodically phytoplankton monitoring would serve as a measure to prevent sudden mass mortality caused by excessive algal increases. Mainly filamentous algae cause acute stress response or mass mortality due to asphyxia in the fish. Besides, scums forming by algae in ponds result in unwanted effects. For these reasons, algal blooms cause economic losses in farming land ponds. Fish mortality due to oxygen deficiency can record despite the use of ventilation systems in the ponds without light and unless photosynthesis in the evening times.

Determining the phytoplankton composition takes an important place in a successful fish farming management strategy. In conclusion, it is necessary to constantly monitor and control the phytoplankton composition as well as the physical and chemical variables of the water used in aquaculture, for obtaining maximum and high-quality yield.

\section{References}

[1] A. Bhatnagar, P. Devi, Water quality guidelines for the management of pond fish culture, Int. J. Environ. Sci., 3 (2013) 1980-2009.

[2] A. Korkut, A. Kop, N.D. Erol, A. Cihaner, Determination methods of growth performance in fish feeding, E.U. J. Fish. Aquat. Sci., 24 (2007) 201-205.

[3] N. Özdemir, S. Dirican, Aquaculture and its problems in Muğla Province, E.U. J. Fish. Aquat. Sci., 23 (2006) 283-286.

[4] D. Das, A. Pathak, S. Pal, Diversity of phytoplankton in some domestic wastewater-fed urban fish pond ecosystems of the Chota Nagpur Plateau in Bankura, India, Appl. Water Sci., 8 (2018) 1-13.

[5] K.S. Park, H.W. Shin, Studies on phyto-and-zooplankton composition and its relation to fish productivity in a west coast fish pond ecosystem, J. Environ. Biol., 28 (2007) 415-422.

[6] R. Alonso-Rodríguez, F. Páez-Osuna, Nutrients, phytoplankton and harmful algal blooms in shrimp ponds: a review with special reference to the situation in the Gulf of California, Aquaculture, 219 (2003) 317-336.

[7] A. Affan, A.S. Jewel, M. Haque, S. Khan, J.-B. Lee, Seasonal cycle of phytoplankton in aquaculture ponds in Bangladesh, Algae, 20 (2005) 43-52.

[8] E.G. Bellinger, D.C. Sigee, Freshwater Algae Identification, Enumeration and Use as Bioindicators, 2nd ed., John Wiley \& Sons, Ltd., The Atrium, Southern Gate, Chichester, West Sussex, UK, 2015.

[9] A. Pradhan, P. Bhaumik, S. Das, M. Mishra, S. Khanam, B. Amin Hoque, I. Mukherjee, A.R. Thakur, S.R. Chaudhuri, Phytoplankton diversity as indicator of water quality for fish cultivation, Am. J. Environ. Sci., 4 (2008) 271-276.

[10] J.A. Plumb, L.A. Hanson, Health Maintenance and Principal Microbial Diseases of Cultured Fishes, Wiley-Blackwell Publishing Ltd., Iowa, USA, 2011.

[11] N. Yilmaz, I.I. Ozyigit, G. Demir, I.E. Yalcin, Determination of phytoplankton density, and study of the variation of nutrients and heavy metals in the surface water of Riva Stream; one of the water sources of Istanbul, Turkey, Desal. Water Treat., 55 (2015) 810-820.

[12] N. Yilmaz, C.H. Yardimci, M. Elhag, C.A. Dumitrache, Phytoplankton composition and water quality of Kamil Abduş Lagoon (Tuzla Lake), Istanbul-Turkey, Water, 10 (2018) 1-13.

[13] N. Yilmaz, I.I. Ozyigit, H.H. Demir, I.E. Yalcin, Assessment on phytoplankton composition and heavy metal pollution in a drinking water resource: Lake Terkos (Istanbul, Turkey), Desal. Water Treat., 225 (2021) 265-274.

[14] M.D. Guiry, G.M. Guiry, AlgaeBase, World-Wide Electronic Publication, National University of Ireland, Galway, 2017. Available at: http://www.algaebase.org., searched on 25 November 2017.

[15] F. Hustedt, Bacillariophyta (Diatomeae) heft 10, in Die Süsswasser-flora Mitteleuropas, A. Pascher, Ed., Gustav Fischer Publications, Jena, Germany, 1930.

[16] T.V. Desikachary, Cyanophyta, Monograph on Algae, Botany Department, University of Madras, New Delhi, India, 1959.

[17] G.W. Prescott, Algae of Western Great Lake Area, W.M.C. Brown Co. Publishers, Dubuque, USA, 1961.

[18] G.W. Prescott, Fresh Water Algae, W.M.C. Brown Co. Publishers, Dubuque, USA, 1964.

[19] R. Patrick, C.W. Reimer, The Diatoms of the United States: Exclusive of Alaska and Hawaii, Vol. 1, The Academy of Natural Sciences, Philadelphia, USA, 1966.

[20] R. Patrick, C.W. Reimer, The Diatoms of the United States: Exclusive of Alaska and Hawaii, Vol. 2, The Academy of Natural Sciences, Philadelphia, USA, 1975.

[21] F. Hustedt, The Pennate Diatoms, Koeltz Scientific Books, Koeningstein, Germany, 1985.

[22] G. Huber-Pestalozzi, Das Phytoplankton des Süsswassers: Systematik und Biologie: 2. Teil, 2. Halfte: Diatomeen, in Die Binnengewasser, A. Thienimann Teil 2 Diatomeen, Ed., E. Schweizerbartsche Verlagsbuchhandlung, Stuttgard, Germany, 1942.

[23] K. Krammer, H. Lange-Bertalot, Bacillariophyceae: Teil 3. Centrales, Fragilariaceae, Eunotiaceae, Gustav Fischer Verlag, Jena, Germany, 1986.

[24] D.M. John, B.A. Whitton, A.J. Brook, The Freshwater Algal Flora of the British Isles, Cambridge University Press, New York, USA, 2009.

[25] C.M. Palmer, A composite rating of algae tolerating organic pollution, J. Phycol., 5 (1969) 78-82.

[26] Ş. Yıldırım, A. Alpbaz, An investigation on some of the production characteristics of the fish farms in Turkish Seas whose annual productions are 100 tonnes and over, E.U. J. Fish. Aquat. Sci., 22 (2005) 251-255.

[27] R.E. Yardimci, Diagnosis of vibriosis involving members of the splendidus clade in cultured european seabass (Dicentrarchus labrax) in Turkey, Israeli J. Aquacult.-Bamidgeh, 72 (2020) 1-11.

[28] S. Akter, M.M. Rahman, A. Faruk, M.N.M. Bhuiyan, A. Hossain, A.A. Abdulla, Qualitative and quantitative analysis of phytoplankton in culture pond of Noakhali district, Bangladesh Int. J. Fish. Aquat. Stud., 6 (2018) 371-375.

[29] C. Kruk, N. Mazzeo, G. Lacerot, C.S. Reynolds, Classification schemes for phytoplankton: a local validation of a functional approach to the analysis of species temporal replacement, J. Plankton Res., 24 (2002) 901-912.

[30] C.S. Reynolds, V. Huszar, C. Kruk, L. Naselli-Flores, S. Melo, Towards a functional classification of the freshwater phytoplankton, J. Plankton Res., 24 (2002) 417-428.

[31] M.K. Kim, J.W. Park, C.S. Park, S.J. Kim, K.H. Jeune, M.U. Chang, J. Acreman, Enhanced production of Scenedesmus spp. (green microalgae) using a new medium containing fermented swine wastewater, Bioresour. Technol., 98 (2007) 2220-2228.

[32] F.E. Round, The Ecology of Algae, Cambridge University Press, Cambridge, 1984.

[33] D.W.Smith, R.H.Piedrahita, The relation between phytoplankton and dissolved oxygen in fish ponds, Aquaculture, 68 (1998) 249-265.

[34] K. Kunlasak, C. Chitmanat, N. Whangchai, J. Promya, L. Lebel, Relationships of dissolved oxygen with chlorophyll-a and 
phytoplankton composition in tilapia ponds, Int. J. Geosci., 4 (2013) 46-53.

[35] P. Sriyasak, C. Chitmanat, N. Whangchai, J. Promya, L. Lebel Effect of water de-stratification on dissolved oxygen and ammonia in tilapia ponds in Northern Thailand, Int. Aquat. Res., 7 (2015) 287-299.

[36] K. Buragohain, S. Gupta, Chlorophyll dynamics of Euglena infested ponds in Barak Valley, Assam, North East India, Ecol. Environ. Conserv. Paper, 16 (2010) 133-137.

[37] M.K. Mustapha, Seasonal influence of limnological variables on plankton dynamics of a small, shallow, Tropical African Reservoir, Asian J. Exp. Biol. Sci., 1 (2010) 60-79.
[38] E. Zebek, U. Szymanska, Abundance, biomass and community structure of pond phytoplankton related to the catchment characteristics, Knowl. Manage. Aquat. Ecosyst., 418 (2017) 1-9.

[39] R. Edziyie, P. Perschbacher, A study on the effects of propanil on the water quality and plankton communities of channel Catfish (Ictalurus punctatus) pond systems with and without a floating algal scum, J. Fish. Livest. Prod., 5 (2017) 1-4. 